\title{
Strategi Guru Dalam Mengelola Kelas di Sekolah Dasar
}

\author{
Faizhal Chan ${ }^{1 *}$, Agung Rimba Kurniawan ${ }^{2}$, Nurmaliza ${ }^{3}$, Novia Herawati ${ }^{4}$, Rendi Nur
} Efendi $^{5}$, Jihan Sri Mulyani ${ }^{6}$

123456Universitas Jambi

\section{A R T I CLEINFO}

Article history:

Received 18 August 2019

Received in revised form

19 September 2019

Accepted 25 October 2019

Available online 30

November 2019

\section{Kata Kunci:}

Strategi, Guru, Pengelolaan

Kelas.

Keywords:

Strategy, Teacher,

Classroom Management.

\begin{abstract}
A B S T R A K
Penelitian ini bertujuan untuk mendeskripsikan tentang Strategi Guru dalam mengelola kelas di Sekolah Dasar .Penelitian ini dilakukan di SD Negeri 155/l Sungai Buluh pada awal Juli 2019 hingga bulan agustus 2019. Data dari penelitian ini diperoleh melalui awancara bersama guru kelas yang hasilnya sebagai data pendukung dari sumber utama serta observasi menegenai pengelolaan kelas. Setelah dilakukan pengumpulan data kemudian diakukan terhadap instrumen tersebut secara kualitatif. Hasil penelitian menunjukkan tentang Strategi Guru dalam Mengelola Kelas di Sekolah Dasar bahwa wali kelas IV dalam pengelola kelas sudah baik hal ini dibuktikan dengan keadaan ruangan kelas yang tertera dengan baik dan rapi. Dengan membuat kelas penuh dengan karya siswa dan mengutamakan keaktifan siswa selama proses belajar mengajar berlangsung, serta siswa juga ikut dalam menjaga keindahan kelas. Untuk mengatur sirkulasi udara agar tidak mengganggu saat proses pembelajaran jendela tetap di buka dan fentilasi udara selalu dibersihkan setiap hari.
\end{abstract}

\section{A B S T R A C T}

This study aims to describe the Teacher Strategy in managing classes in Elementary Schools. This research was conducted at SD Negeri 155 / I Sungai Buluh in early July 2019 until August 2019. Data from this study were obtained through an interview with classroom teachers whose results were as supporting data from main sources and observations regarding class management. After data collection, the instrument is carried out qualitatively. The results showed about the Teacher Strategy in Managing Classes in Elementary Schools that the fourth grade guardian in the classroom manager was good this was evidenced by the condition of the classrooms that were listed well and neatly. By making the class full of student work and prioritizing student activity during the teaching and learning process, and students also participate in maintaining the beauty of the class. To regulate air circulation so as not to disturb during the learning process the window remains open and air fentilation is always cleaned every day.

\footnotetext{
${ }^{1}$ Corresponding author.

E-mail addresses: rendinurefendi@gmail.com (Faizhal Chan)
} 


\section{Pendahuluan}

Proses pembelajaran dan kegiatan pengelolaan kelas adalah dua hal yang saling berkaitan, namun dalam keterkaitan pengelolaan kelas tersebut memiliki perbedaan karena keduaanya memiliki tujuan yang berbeda. Jika pembelajaran mencakup semua kegiatan yang berlangsung dalam proses pembelajaran untuk dapat mencapai tujuan-tujuan khusus tertentu, sedangkan pengelolaan kelas ditunjukkan untuk menciptakan dan mempertahankan kondisi optimal yang aktif dalam proses pembelajaran Wiyani (2013:139)

Upaya untuk mengaktifkan dan menghidupkan ruang kelas dalam rangka melaksanakan proses pembelajaran serta pengelolaan kelas yang efektif mampu mengarahakan pada tercapainya tujuan pembelajaran yang diharapakan dan hal itu membutuhkan sikap dari berbagai hal yang terlibat dalam kegiatan pembelajaran. Dalam keseharian guru di tuntut agar dapat berkembang secara percaya diri maupun mandiri dalam meningkatkan kreativitasnya. Guru menciptakan suasana kondusif untuk belajar dan memungkinkan peserta didik dapat berekspresi dengan bebas, menyenangkan dan penuh gairah dalam belajar untuk mempelajari dan memahami esensi berbagai hal yang mereka pelajari.

Mengatur lingkungan fisik, bagi pembelajaran merupakan langkah awal dalam melaksanakan pengelolaan kelas, karena hal ini merupakan sebuah tugas yang dihadapi semua guru sebelum kegiatan pembelajaran dimulai. Oleh karena itu, guru tidak hanya cukup memahami tentang kondisi peserta didik semat namun juga harus dapat memahami dan mengenal tengtang lingkungan fisik yang akan digunakan sebagai tempat kegiatan pembelajaran.

Selama kegiatan pembelajaran peserta didik pun harus dapat dibimbing dan disiapkan agar dapat terbiasa dalam situasi yang mengandalkan sikap kemandirian peserta didik dan penuh dengan inovasi sehingga diharapkan mereka tidak lagi pasif menunggu dan menyikapi intruksi dari guru. Tanpa ada upaya perubahan tersebut tentu proses pembelajaran tidak akan dapat berkembang. Melaksanakan kegiatan pembelajaran di kelas merupakan salah satu tugas guru sebagai pendidik profesional. Bahkan sebagian besar tugas guru sering dihabiskan untuk melaksanakan kegiatan pembelajaran di ruang kelas, sehingga wajar kiranya jika guru memberikan perhatian lebih terhadap ruang kelas sebagai tempat belajar yang lebih sering digunakan oleh peserta didik. Itulah sebabnya seorang guru dikatakan harus memiliki keterampilan dalam pengelolaan kelas.

Guru sebagai sebagai pengelola kelas, dalam perannya, guru hendaknya mampu mengelolakelas karena kelas merupakan lingkungan belajar serta merupakan sautu aspek dari lingkungan sekolah yang perlu di organisasi, lingkungan ini di atur dan di awasi agar kegiatan - kegiatan belajar terarah kepada tujuan-tujuan pendidikan. Pengeloalan kelas yang dilaksanakan dengan baik maka akan dapat berimplikasi pada kegiatan pembelajaran yang bermutu, pembelajaran yang bermutu yang dapat terlaksana akan dapat pula berpengaruh pada keberhasilan suatu pembelajaran oleh guru dan peserta didik .

Guru merupakan suatu pekerjaan yang mulia. Apabila, para guru melakukan tugasnya secara ikhlas dan berdasarkan suara hatinya, maka mereka sudah memiliki "tiket masuk surga". Apabila, guru dalam mendidik muridnya dilandasi dengan kasih sayang, maka mereka juga akan mendapat tambahan bonus dicintai oleh para muridnya. Dengan demikian, guru yang baik akan memperoleh tiga "gaji" sekaligus. Yaitu, "gaji" ekonomis (uang), "gaji" teologis (amal ibadah), dan "gaji" sosial (kesan dan ingatan yang baik dari para muridnya, paling tidak didoakan) (Warsono, 2017).

Pengelolaan kelas merupakan salah satu aspek dari pengelolaan proses pembelajaran yang paling rumit, tetapi menarik perhatian, baik oleh guru yang sudah berpengelaman maupun guru-guru muda yang baru bertugas Mulyadi (2018:9) Dikatakan rumit karena pengelolaan kelas merupakan hal yang memerlukan berbagai kriteria keterampilan, pengelaman, dan juga sikap serta kepribadian guru memiliki pengaruh terhadap pengelolaan kelas yang di laksanakan .

Pelaksanaan Pengelolaan kelas dapat dilakukan dalam berbagai hal misalnya, penataan fisik ruang kelas, membangun lingkungan yang kondusif untuk kegiatan pembelajaran, pengendalian tingkah laku para peserta didik, membangun komunikasi yang baik, dan lain sebagainya. Sehingga dapat meminimalisir timbulnya kejenuhan suasana belajar pada peserta didik yang berimbas pada kegiatan pembelajaran yang tidak efektif dan efisien.

Timbulnya kegiatan pembelajaran yang tidak efektif dan tidak efisien akan sangat mendukung terjadinya kegiatan pembelajaran yang tidak berkualitas, dengan adanya hal itu akan menyebabkan tujuan pembelajaran tidak akan dapat tercapai dan peserta didik tidak akan mendapatkan apa-apa atas kegiatan belajar mereka. Maka strategi pengelolaan kelas yang tepat sangat diperlukan untuk diciptakan oleh guru dalam perencanaan proses pembelajaran. Pengelolaan kelas adalah segala usaha yang diarahkan oleh guru untuk mewujudkan suasana pembelajaran yang efektif dan menyenangkan serta dapat memotivasi 
peserta didikuntuk belajar denganbaik sesuai kemampuan Segala usaha yang dilakukan untuk memperlancar kegiatan pembelajaran adalah tanggung jawab guru.

Usaha-usaha yang dilakukan melalui upaya pemanfaatan segala sumber daya yang ada dan tersedia di dalam kelas. Selain itu, pengelolaan kelas memang berfungsi untuk mengelola tingkah laku peserta didik dalam kelas, menciptakan iklim yang kondusif emosional, dan mengelola proses belajar kelompok yang efektif. Sejauh ini, strategi pengelolaan kelas yang telah,dilakukan dinilai oleh para guru sangat membantu dalam menciptakan suasana pembelajaran yang menarik dan menantang bagi para peserta didik. Sehingga hal itu pun menjadi sebuah pemicu bagi para guru untuk terus berinovasi dalam mengembangkan pengelolaan kelas yang lebih baik lagi.

Suatu sistem pendidikan dikatakan berkualitas apabila proses pembelajarannya dapat berlangsung dengan Menarik dan menantang. Redho harsanto (2017:9) Terkait dengan hal itu, salah satunya yang diperlukan dalam sistem pendidikan adalah inovasi dalam strategi pengelolaan kelas sehingga diperolehlah suasana belajar yang baru dan bervariasi, yang pada akhirnya diharapkan dapat menciptakan pembelajaran yang menarik dan menantang sesuai dengan perkembangan para peserta didik.

Berdasarkan pengamatan di SD Negeri 155/I Sungai Buluh. peneliti menemukan diruang kelas IV memiliki tata ruang yang baik dan sangat nyaman. Oleh karena itu, peneliti tertarik mengambil masalah Strategi Guru Dalam Mengelola Kelas di Sekolah Dasar berdasarkan latar belakang diatas, permasalahan yang diangkat dalam penelitian ini adalah bagaimanakah startegi guru dalam mengelola kelas disekolah dasar, dengan adanya penelitian ini, guru bisa mengetahui bagaimana strategi yang baik untuk melaksanakan proses pembelajaran yang baik disekolah dasar.

Strategi adalah sebuah rencana yang komphenrenshif mengintegrasikan segala resounsces dan capabities yang mempunyai tujuan jangka panjang untuk memenangkan kompetensi. Sedangkan menurut Miller (2007:139) strategi akan cukup mudah bagi kita akan menentukan kemana kita mencari. Wheelen dan hunger(2003:217) strategi merupakan serangkaian keputusan dan tindakan menajarial yang menentukaan kinerja sekolah dalam jangka panjang.

Dari pengertian di atas maka dapat di tarik kesimpulan bahwa strategi di artikan suatu proses untuk menentukan arah yang di jalani oleh suatu organisasi agar tujuannya tercapai. Dengan adannya strategi, maka suatu organisasi akan dapat memperoleh kedudukan atau posisi yang kuat dalam wilayah kerjannya

Salah satu tugas guru yang tidak pernah ditinggalkan adalah mengelola kelas. Guru selalu mengelola kelas ketika dia melaksanakan tugasnya. Pengelolaan kelas dimaksudkan untuk menciptakan lingkungan belajar yang kondusif baik peserta didik sehingga tercapai tujuan pembelajaran secara efektif dan efisien. Ketika kelas terganggu, guru berusaha mengembalikannya agar tidak menjadipenghalang bagi proses belajar mengajar. Suryani dan Agung (2012: 185) berpendapat dalam konteks yang demikian itulah kiranya pengelolaan kelas penting untuk diketahui oleh siapapun juga yang menerjunkan dirinya ke dalam dunia pendidikan. Oleh karena itu, kiranya penting untuk mengetahui pengertian pengelolaan kelas. Pengelolaan itu sendiri akarnya adalah "kelola", ditambah awalan "pe" dan akhiran "an". Istilah lain dari kata pengelolaan adalah manajemen." Manajemen adalah kata yang aslinya dari bahasa inggris, yaitu management, yang berarti ketatalaksanaan, pengelolaan.

Menurut Djamarah dan Zain (2010:174) pengelolaan kelas adalah satu tugas guru yang tidak pernah ditinggalkan. Guru selalu mengelola kelas ketika dia melaksanakan tugasnya. Pengelolaan kelas dimaksudkan untuk menciptakan lingkungan belajar yang kondusif bagi anak didik sehingga tercapai tujuan pengajaran secara efektif dan efisien. Ketika kelas terganggu, guru berusaha mengembalikannya agar tidak menjadi penghalang bagi proses belajar mengajar. Suryani dan Agung (2012: 187) juga berpendapat pengelolaan kelas merupakan suatu usaha menyiapkan kondisi yang optimal agarproses atau kegiatan belajar mengajar dapat berlangsung secara tertib dan lancar.Dalam hal ini guru bertugas menciptakan, mempertahankan dan memeliharasistem/organisasi kelas, sehingga siswa dapat memanfaatkan kemampuannya,bakatnya dan energinya pada tugas-tugas baik individual maupun kelas.

Menurut Sardiman (2004:25) bahwa tujuan pengelolaan kelas adalah sebagai berikut:

1) Mewujudkan situasidan kondisi kelas, baik sebagai lingkungan belajar maupun sebagai kelompok belajar yang memungkinkan peserta didik untuk mengembangkan kemampuan semaksimal mungkin.

2) Menghilangkan berbagai hambatan yang dapat menghalangi terwujudnya interaksi belajar mengajar.

3) Menyediakan dan mengatur fasilitas serta perabot belajar yang mendukung dan memungkinkan peserta didik belajar sesuai dengan lingkungan sosial, emosional, dan intelektual peserta didik di dalam kelas.

4) Membina dan membimbing sesuai dengan latar belakang sosial ekonomi budaya serta sifat-sifatnya individunya. 
5) Tujuan pengelolaan kelas menurut sudirman (Djamarah 2006:170) pada hakikatnya terkandung dalam tujuan pendidikan. Tujuan pengelolaan kelas adalah penyediaan fasilitas yang disediakan itu itu memungkinkan peserta didik belajar dan bekerja.

Menurut Rohani ahmad (2004: 157) terdapat beberapa faktor penghambat pengelolaan kelas antara lain yaitu: (a) faktor guru, (b) faktor pesertadidik, (c) faktor keluarga, dan (d) faktor fasilitas. Fungsi Guru dalam Mengelola Kelas atau Guru Sebagai Manager Adapun tugas dan fungsi seorang menager adalah menejer orang-orang yang dipimpinnya agar mau berbuat sesuai dengan keinginannya dalam rangka mencapai tujuan organisasi. Berkenaan guru sebagai menager kelas maka tugas dan fungsinya adalah menggerakan siswa-siswanya dengan mempengaruhi, membimbing, memotivasi dan mengarahkan agar siswa-siswa itu berbuat atau berprilaku sesuai dengan tujuan yang ingin dicapai dalam kegiatan proses belajar mengajar. Zuldafiar (2011:77).

Wali Kelas Sebagai Administrator Perlu diketahui terlebih dahuluperbedaan pengertian antara menagement dan administrasi, untuk mengetahui lebih dalam tentang apa tugas atau fungsi wali kelas sebagai administrator. Zuldafarial ( 2011:82)

Telah lama diperdebatkan orang-orang tentang jawaban atau pertanyaan manakah yang lebih luas administrasi atau menagement. Bermacam-macam pendapat telah dikemukakan oleh para sarjana administrasi. Pendapat tersebut antara lain mengatakan bahwa kedua istilah tersebut dipandang sebagai kata-kata yang sama artinya, bila dipakai untuk tujuan-tujuan praktis, tetapi beberapa ahli yang lain cenderung untuk mengartikan administrator itu sama dengan Top Menagement dan menganggap administrasi itu mengandung penentuan-penentuan. Dalam arti yang demikian maka orang-orang yang mempunyai tugas untuk memimpin, menjuruskan dan mengawasi adalah menager-menager dan hanya mereka yang ikut serta secara luas dalam keputusan-keputusan kebijaksanaan adalah administratoradministrator.

Pendapat lain mengatakan bahwa menagement adalah merupakan inti dari pada administrasi, karena menagement merupakan alat pelaksanaan utama dari pada administrasi. Dalam melaksanakan tugasnya, menagement tidak melaksanakan sendiri kegiatan-kegiatan yang bersifat operasional, melainkan mengatur tindakan-tindakan pelaksanaan oleh sekelompok orang yang disebut bawahan. Dengan demikian keberhasilan administrasi sangat tergantung sekali pada keberhasilan dalam menagement.

Menurut Purnomo (2005:3) pengertian tentang kelas yang dikemukakan oleh Purnomo, bahwa “ kelas adalah ruangan belajar ( lingkungan fisik) dan rombongan belajar ( lingkungan emosional)". Lingkungan fisik meliputi : (1) ruangan, (2) keindahan kelas, (3) pengaturan tempat duduk, (4) pengaturan serana dan alat pengajaran, (5) ventasi dan pengaturan cahaya. Sedangkan lingkungan sosio emosional meliputi: (1) tipe kepemimpian guru, (2) sikap guru. (3) suara guru, (4) pembinaan hubungan yang baik.

Kelas bukanlah sekedar rungan dengan segala isinya yang bersifat statis dan pasif, namun kelas juga merupakan serana berinteraksi antara peserta didik dengan peserta didik dan peserta didik dengan guru. Ciri utama kelas adalah pada aktivitasnya untuk dapat menjalankan aktivitas atau kegiatan pembelajaran yang dinamis perlu adanya suatu aktivitas pengelolaan kelas baik dan terancana.

Dalam kamus besar Bahasa indonesia, istilah pengelolaan kelas di artikan dengan “ penyelenggaraan pengurusan ". Poerwadinata (2002:470) sedangkan yang dimaksud dengan kelas adalah " tingkat, ruang tempat belajar di sekolah". Dengan kata lain pengelolaan kelas di terjemahkan secara singkat sebagai suatu proses penyelengaraan atau pengurusan ruang dimana dilakukan kegiatan belajar mengajar, dan untuk lebih jelasnya berikut pengertian pengelolaan kelas yang dikemukakan oleh Usman( 2002:7), adalah keterampilan guru unutk menciptakan dari memelihara kondusi belajar yang optimal dan mengambilankannya bila terjadi gangguan dalam proses belajar mengajar. Sedangkan menurut Sanjaya ( 2005:174) pengelolaan kelas adalah keterampilan guru menciptakan dan memelihara kondisi belajar yang optimal dan mengembalikannya manakala terjadi hal- hal yang dapat menganggu suasana pembelajaran.

\section{Metode}

Kegiatan Penelitian ini akan dilaksanakan di SD Negeri 155/I Sungai Buluh di kelas IV, Peneliti membatasi penelitian ini hanya pada guru kelas IV. Penelitian ini dilaksanakan pada Semester Ganjil tahun ajaran 2019/2020 di SD Negeri 155/I Sungai Buluh pada tanggal 4 juli 2019 sampai tanggal 9 september 2019.

Pendekatan dalam penelitian ini menggunakan pendekatan kualitatif. Karena penelitian kualitatif lebih sering menggunakan analisis dan kondisi berkembang apa adanya dan digunakan untuk meneliti obyek yang alami baik untuk menguraikan, menggambarkan, mendeskripsikan yang berkaitan dengan 
penelitian yang akan di teliti. selain itu peneliti juga ingin mendalami masalah strategi guru dalam mengelola kelas yang kondusif di sekolah dasar secara lebih jelas dan mendalam.

Menurut Sugiyono (2016:15) Metode Penelitian Kualitatif adalah "metode penelitian yang berlandaskan pada filsafat postpositivisme, digunakan untuk meneliti pada kondisi obyek yang alamiah, (sebagai lawannya adalah eksperimen) dimana peneliti adalah sebagai instrumen kunci, pengambilan sampel sumber data dilakukan secara purvosive dan snowbaal, teknik pengumpulan dengan trianggulasi (gabungan), analisis data bersifat induktif/kualitatif, dan hasil penelitian kualitatif lebih menekankan makna dari pada generalisasi".

Jenis penelitian ini Fenomenalogy dikarenakan jenis penelitian ini meneliti suatu fenomena yang ada dimasyarakat yang dilakukan secara mendalam. Shosha (2012) mengatakan bahwa "Phenomenology is a philosophy and research method designed to explore and understand people's everyday lived experiences".

Dimaksudkan bahwa Fenomenologi adalah filsafat dan metode penelitian yangdirancang untuk mengeksplorasi dan memahami pengalaman hidup. Dan Moleong (2010:15) mengemukakan juga bahwa "Fenomenologi merupakan pandangan berpikir yang menekankan pada fokus kepada pengalamanpengalaman subjektif manusia dan interpretasi-intepretasi dunia". Pengalaman dan hal yang dialami oleh objek penelitian dengan memperhatikan fokus fenomena dengan cara observasi secara mendalam dan wawancara langsung kepada objek yang akan diteliti.

Sumber data terdiri dari hasil wawancara dan observasi pada guru kelas IV SD Negeri 155/I Sungai Buluh. Data dari hasil wawancara dengan guru kelas IV dan observasi di kelas IV. Dengan mengetahui strategi guru dalam mengelola kelas di semester ganjil Peneliti dapat menempatkan Posisi Instrumen yang menjadi penelitian tersebut. Selain itu peneliti mengamati bagaimana strategi guru dalam mengelola kelas yang baik di semester ganjil di SD Negeri 155/I Sungai Buluh.

Sampel pada penelitian ini dinamakan narasumber, partisipan, informan, teman dan Guru. Sampel yang digunakan adalah sampel teoritis karena tujuan penelitian ini menghasilkan teori. Sampling dalam penelitian ini adalah pilihan penelitian mengenai aspek apa, dari peristiwa apa, dan siapa yang dijadikan fokus pada suatu saat dan situasi tertentu, karena itu dilakukan secara terus-menerus sepanjang penelitian. Dalam penelitian ini digunakan teknik sampling yang sering digunakan yaitu:

Purposive sampling pengambilan sampel dengan pertimbangan tertentu. Pada penelitian ini sangat diperlukan Strategi guru dalam mengelola kelas yang kondusif di Sekolah Dasar agar mempermudah peneliti menjelajahi objek atau situasi yang diteliti. Pengambilan sampel berdasarkan kebutuhan yang diperlukan. Dan time sampling mempertimbangkan waktu dan tempat dalam pengumpulan data di SD Negeri 155/I Sungai Buluh dilakukan dengan guru kelas IV mengenai strategi yang dilaksanakan oleh guru tersebut dalam pengelolaan kelas yang baik, yang ditinjau dari proses pembelajaran yang dilaksanakan di dalam kelas.

Pada penelitian ini Teknik pengumpulan data menggunakan 3 teknik yaitu wawancara, observasi dan Dokumentasi.

Wawancara pada penelitian ini berguna untuk mengetahui dan mencari informasi secara mendalam tentang masalah penelitian serta objek yang akan di teliti tentang Strategi guru dalam mengelola kelas yang baik di SD.

Menurut Sugiyono "wawancara digunakan sebagai teknik pengumpulan data apabila peneliti ingin melakukan studi pendahuluan untuk menemukan permasalahan yang harus diteliti, dan juga apabila peneliti ingin mengetahui hal-hal dari responden yang lebih mendalam dan jumlah respondennya sedikit/kecil" (2006:194).

Wawancara yang digunakan dalam penelitian ini adalah wawancara tidak terstruktur, karena peneliti ingin mengetahui informasi tentang masalah penelitian lebih mendalam tentang masalah yang akan diteliti. Menurut Sugiyono mengatakan bahwa "wawancara tidak terstruktur atau terbuka, sering digunakan dalam penelitian atau malahan untuk penelitian yang lebih mendalam tentang responden." (2006:197) .Responden atau informan dalam penelitian ini adalah Guru kelas IV di SD Negeri 155/I Sungai Buluh.

Observasi merupakan salah satu metode pengumpulan data di mana metode pengumpulan data mengamati secara visual gejala yang diamati serta menginterprestasikan hasil pengamatan tersebut dalam bentuk catatan sehingga validitas data sangat tergantung pada kemampuan observer.

Dokumentasi dijadikan pelengkap dan pendukung dalam pengumpulan data pada penelitian ini. Dokumentasi dalam penelitian ini yaitu apabila diperlukan dokumen-dokumen tertulis maupun gambar/foto-foto dari observasi dan wawancara.

Uji validitas data sehingga diperoleh kesahihahan data dilakukan trianggulasi. Sesuai pendapat Sugiyono (2015:330) "mengemukakan bahwa triangulasi adalah suatu penggabungan dari berbagai teknik pengumpulan data dan sumber data yang telah tersedia". Diadaptasi dari Bachri (2010:56) 
triangulasi ada berbagai macam cara, yaitu :

1. Triangulasi Metode

Usaha mencek keabsahan data atau mencek keabsahan temuan penelitian. Dalam penelitian ini, triangulasi metode dilakukan dengan cara menggunakan dua teknik pengumpulan data, yaitu wawancara, observasi.

2. Triangulasi Teknik

Dalam hal mengumpulkan data menggunakan teknik yang berbeda-beda tetapi dalam sumbernya yang sama. Dimana teknik yang digunakan Guru itu berbeda-beda tetapi dalam sumber yang sama ketika mengumpulkan data.

Pada proposal penelitian ini melakukan pengumpulan dengan wawancara tidak bersruktur (mendalam), observasi nonpartisipan, maka peneliti menggunakan triangulasi sumber dan teknik karena pada penelitian ini absha/syahnya data yang dikumpulkan dipengaruhi oleh teknik dan sumber yang digunakan. Strategi Guru tersebut dan sumbernya ada pada Guru kelas IV Di SD Negeri 155/I Sungai Buluh.

Analisis data dapat dilakukan dengan cara yaitu analisis kualitatif. Analisis data yang pertama adalah mencatat data yang telah didapatkan dari informan dan memberi kode supaya sumber data dapat ditelusuri. Kedua Analsis akan dilakukan dengan 3 tahapan diadopsi dari Miles \& Huberman dalam (Sugiyono, 2015:337-345) :

1. Reduksi Data

Reduksi data adalah proses merangkum, memilih dan memfokuskan data pada hal-hal penting, sehingga memberikan gambaran untuk mempermudah peneliti. Pada tahap ini peneliti menentukan kesimpulan atau pokok-pokok tentang objek yang sedang diteliti agar penelitian lebih terarah dan dapat dengan mudah dipastikan kebenarannya. Dengan kata lain, reduksi data dilakukan agar dapat memberi pandangan yang lebih jelas tentang hasil wawancara dan observasi.

2. Penyajian Data

Penyajian data adalah proses untuk menyusun dan mengorganisasikan data supaya mudah dipahami. Menurut Sugiyono (2015:341) mengatakab bahwa penyajian data kualitatif bisa dilakukan dengan uraian singkat, bagan, hubungan antar kategori, flowchart, dan sejenisnya.

3. Penarikan Kesimpulan

Setelah data direduksi dan disajikan maka tahap terakhir adalah penarikan kesimpulan. Menyimpulkan berarti menemukan fakta baru dari proses tindakan yang telah dilakukan. Kesimpulan awal akan dikemukakan masih bersifat sementara, dan akan berubah bila tidak ditemukan bukti-bukti yang kuat dan mendukung pada tahap selanjutnya.

Prosedur atau langkah-langkah penelitian ini diawali dengan penentuan objek yang akan diteliti, yaitu dilaksanakan di SD Negeri 155/I Sungai Buluh. Pemilihan tempat tersebut didasari oleh landasan dari penelitian ini, yaitu, Strategi Guru dalam mengelola kelas yang baik di Sekolah Dasar oleh karena itulah dapat menjadi tolak ukur ketika pengumpulan data selanjutnya.

Apabila telah menentukan lokasi penelitian atau objek penelitian, maka langkah selanjutnya adalah menetapkan fokus masalah penelitian. Fokus masalah penelitian ini adalah Strategi Guru dalam mengelola kelas yang Kondusif di Sekolah Dasar yang disertai oleh pembuatan instrumen penelitian yang mendukung terlaksananya penelitian ini.

Instrumen yang digunakan adalah observasi, wawancara yang telah dikembangkan berdasarkan penelitian terdahulu. Penelitian yang terdahulu didominasi oleh instrumen penelitian yang berupa observasi. Tentunya instrumen yang digunakan oleh peneliti tingkat kepercayaannya.

Setelah semua data terkumpulkan, maka langkah selanjutnya adalah data tersebut dianalisis dengan menggunakan model Miles dan Hubermann dengan tahapan awal adalah reduksi-penyajian datapenarikan kesimpulan. Berdasarkan hasil kesimpulan itulah dieroleh informasi mengenai hasil penelitian.

Walaupun demikian, kesimpulan dari penelitian ini mungkin saja dapat menjawab rumusan masalah yang dirumuskan sejak awal, tetapi mungkin juga tidak, sebab masalah dan rumusan masalah dalam penelitian kualitatif masih bersifat sementara dan akan berkembang setelah penelitian berada di lapangan.

\section{Hasil dan Pembahasan}

Berdasarkan Penelitian ini dilakukan pada kelas IV dengan subjek penelitian adalah wali kelas. Pengambilan data dilakukan dengan melalui kegiatan Observasi terlebih dahulu pada saat siswa mengikuti pembelajaran selanjutnya data di peroleh dengan melalui wawancara mendalam kepada guru 
kelas IV, Berikut akan dipaparkan hasil dari data temuan yang diperoleh.

Berdasarkan observasi yang peneliti laksanakan pada tanggal 4 juli 2019 di SD Negeri 155/I Sungai Buluh pada kelas IV peneliti mengamati secara umum ruang kelas IV baik keadaan siswa, guru, pengaturan tempat duduk siswa, kebersihan kelas, pengaturan udara, pengaturan hiasan yang di dalam ruangan kelas. Peneliti juga melihat secara keseluruhan hal tersebut yang ada di dalam ruang kelas sudah tampak baik, nyaman dan rapi untuk suasana belajar yang kondusif.

Pada tanggal 11 Juli 2019 peneliti melanjutkan observasi dengan memfokuskan pada keadaan ruang kelas dan pengaturan meja siswa, ruang kelas tampak indah dengan hiasan yang ditempel di dinding-dinding kelas yang merupakan hasil karya siswa-siswi kelas IV , buku-buku tersusun dengan rapi di belakang tempat duduk siswa, bahan ajar dan perangkat pembelajaran lengkap di dalam kelas, lembar portofolio siswa juga tersusun dengan rapi di dalam kelas, taman yang berada di depan kelas terlihat indah dan subur. selanjutnya pengaturan meja siswa berdasarkan materi pembelajaran siswa, siswa bisa berpindah-pindah tempat duduk setiap hari. Hal ini dilakukan berdasarkan hasil wawancara dengan wali kelas agar siswa yang belum memahami pembelajaran lebih terfokus dengan materi yang belum dipahaminya dan juga dengan adanya roling tersebut siswa menjadi lebih memahami pembelajaran.

Dari hasil observasi yang peneliti temukan pada observasi sebelumnya peneliti melanjutkan observasi pada tanggal 12 Juli 2019dengan memfokuskan kepada kebersihan kelas dan keadaan siswa, dalam observasi yang peneliti laksanakan peneliti melihat kelas terlihat bersih, meja-meja dan kursi tersusun rapi, lantai kelas terlihat bersih, peralatan atau perabot kelas lengkap dan bahan ajar yang ada di kelas tersusun dengan rapi, berdasarkan hasil wawancara dan observasi yang peneliti laksanakan semua siswa-siswi bekerja sama dalam menjaga kebersihan kelas, dan semua siswa melaksanakan piket kelas sesuai dengan jadwal yang telah dibuat. Kemudian peneliti juga mengamati keadaan siswa di kelas saat pembelajaran maupun diluar pembelajaran. Siswa didalam pembelajaran terlihat aktif, semangat, dan sopan. Berdasarkan hasil wawancara dengan wali kelas bahwa rata-rata siswa kelas IV memiliki daya tangkap yang tinggi hal ini peneliti lihat dari cara belajar siswa di dalam kelas. Peneliti juga melihat keadaan siswa diluar jam pembelajaran siswa terlihat beradaptasi dengan baik dengan teman-temannya yang lain, tidak memilih teman dalam bergaul, saling mengayomi dan saling membantu teman.

Pada tanggal 12 Juli 2019 peneliti melanjutkan observasi dengan memfokuskan pada pengaturan udara dan perabot kelas IV , berdasarkan hasil pengamatan yang peneliti laksanakan peneliti melihat di dalam kelas terdapat ventilasi dan jendela yang berada di samping kiri dan kanan siswa yang membuat kelas terlihat terang dan udara mudah masuk sehingga siswa-siswi menjadi betah saat belajar. Selain itu, perabot yang berada di dalam kelas maupun di luar kelas sudah lengkap, di dalam kelas terdapat meja guru, rak buku, papan karya siswa ,rak sepatu siswa, tikar sebagai tempat belajar siswa, diluar kelas terdapat pot-pot bunga, tong sampah dan hal lain yang mendukung kebersihan kelas. Dari hasil penelitian yang peneliti laksanakan peneliti melihat semua yang ada di kelas di kelola dengan baik oleh wali kelas dan di dukung oleh pihak sekolah dengan kerjasama dengan siswa dalam menjaga ketentraman kelas. Wali kelas IV mengelola kelas dengan baik, sehingga mendukung siwa dalam pembelajaran.

Wawancara dengan wali kelas di lakukan di Sekolah SD Negeri 155/I Sungai Buluh pada tanggal 31 Agusturs 2019 pada waktu jam istirahat berlangsung sehingga proses wawancara tidak menganggu proses belajar mengajar yang terjadi di dalam kelas. Peneliti melakukan wawancara dengan wali kelas untuk mengatahui Strategi guru dalam mengelola kelas yang di kelas.

\section{Simpulan dan Saran}

Berdasarkan hasil penelitian yang peneliti lakukan di SD Negeri 155/I Sungai Buluh, maka dapat ditarik kesimpulan mengenai Strategi guru dalam mengelola kelas di Sekolah yaitu dengan membuat kelas penuh dengan karya-karya siswa, mengutamakan keaktifan siswa selama proses belajar mengajar berlangsung, menggunakan pendekatan keterampilan dalam pembelajaran agar siswa bisa menguasai keterampilan dalam mengelola kelas, dengan melakukan rolling pengaturan tempat duduk siswa yang sudah mampu mengusai pembelajaran dipindahakan ke tempat duduk belakang sedangkan siswa yang belum menguasai pembelajaran dipindahkan duduk di depan agar lebih fokus pada materi yang di sampaikan, menciptakan media pembelajaran dari keterampilan siswa, Selanjutnya guru juga mengatur sirkulasi udara agar tidak menganggu saat proses pembelajaran jendela akan tetap dibuka dan fentilasi udara selalu dibersihkan setiap hari dan menanamkan toleransi dan sikap saling menghargai sesama teman di sekolah maupun diluar jam sekolah.

Peneliti mengajukan beberapa saran dan beberapa masukan terhadap strategi guru dalam mengelola kelas. Saran tersebut diantaranya sebagai berikut:

1. Untuk kepala sekolah agar selalu mencari dan melaksanakan pedoman atau aturan apabila program bimbingan belajar dilaksanakan di SDNegeri 155/I Sungai Buluh. 
2. Untuk guru kelas lebih meningkatkan kompetensi dan kemampuan didalam melaksanakan strategi mengelola kelas serta mengetahui secara mendalam pelaksanaan strategi guru dalam mengelola kelas agar siswa-siswa lebih optimal didalam menerima materi pembelajaran.

\section{Daftar Rujukan}

Arfani, Junita W and Sugiyono, Sugiyono. "Manajemen Kelas yang Efektif: Penelitiandi Tiga Sekolah Mengah Atas". Jurnal Akuntabilitas, Vol.2 No.1 (2014).

Aulia, Resti and Sontani, Uep Tatang. "Pengelolaan Kelas Sebagai Determinan terhadap Hasil Belajar" Jurnal Pendidikan Manajemen Perkantoran, Vol.3 No.2 (2018) hal. 9-17.

Bonney, Kevin M. "Case Study Teaching Method Improves Student Performance and Perceptions of Learning Gains" Journal of Microbiology \& Biology Education, Vol. 16(1): 21-28 (2015)

Helsa, and Hendriati Agustina. "Kemampuan Manajemen Kelas Guru: Penelitian Tindakan di Sekolah Dasar dengan SES Rendah" Jurnal Psikologi, Vol.16 No.2 (2017) Hal. 89-104

Pradnyantika, L. D., Sudiana, I. K., \& Wiratini, N. M. (2018). Pengelolaan Pembelajaran Kimia Di SMA Negeri 2 Negara. Jurnal Pendidikan Kimia Indonesia, 2(1), 42-49.

Irawati, Intan. “Buku Terjemahan: Manajemen Kelas Komprehensif”. (Jakarta: KENCNA, 2012)

Isbadrianingtyas, Nafi. "Pengelolaan Kelas dalam Pembelajaran Tematik di SD” Jurnal Pendidikan: Teori, Penelitian dan Pengembangan, Vol.1 No.5 (2016)

Muningsih. "Manajemen Kelas Guru Sekolah Dasar" Jurnal Manajer Pendidikan, Vol.9 No.5 (2015) Hal. 699-703

Rahman, Arif. “Manajemen Kelas untuk Guru Sekolah Dasar” (Jakarta: KENCANA, 2015).

Wahyuni, Ayu Nur. "Implementasi Pengelolaan Kelas dalam Meningkatkan Efektivitas Pembelajaran Mata Pelajaran Al-Islam Kelas III di SD Muhammadiyah Surabaya". (Jurnal Pendidikan Islam, Vol.4 No.2 (2015).

Warsono, 2017. Guru: Antara Pendidik, Profesi, Dan Aktor Sosial . Journal of Society \& Media 2017.

Wiyani, Novan Ardy. "Manajemen Kelas: Teori dan Aplikasi Untuk Menciptakan Kelas yang Kondusif" (Jogjakarta: Ar-Ruzz Media, 2014). 